DE DE GRUYTER

OPEN

DOI: $10.1515 /$ aa-2017-0010

\title{
Ethnotextual mental translation and self-translation in African literature
}

Fella Benabed

Fella Benabed is an associate professor at Annaba University (Algeria). She has a doctorate in literature from Annaba University as well as a certificate in Contemporary American Literature from the University of Louisville, Kentucky (USA). In her research, she is interested in postcolonial, narrative and ecological approaches to New Literatures in English and French.

\begin{abstract}
:
Interest in African literature and translation is relatively new; it mainly emerged in the 1990s with the postcolonial turn in translation studies, under the influence of the cultural turn, the polysystems theory and the "Manipulation School". Many African writers describe themselves as intercultural translators; they hover over the following questions: Is it a form of selfdenigration not to use one's mother tongue as a medium of literary creation? How can their literary creations account for their postcolonial experience in the languages of former colonizers? Can these languages render the specificities of their distinct cultural worldviews? The linguistic choice made by African writers is hence highly political because it involves a compromise that rests on power relations. Their writing often involves a sort of translation from Source Language (SL) to Target Language (TL) whether through ethnotextual mental translation or self-translation.
\end{abstract}

\section{Introduction}

Mastery of two languages, with their syntactic and semantic features, is not sufficient to make a good translation; awareness of history and ideology is also an essential requirement. Dealing with African literature, mainly grounded in orature (oral literature), translators need to know not only the Source Language (SL) and the Target Language (TL) but also their underlying cultures in order to build a bridge between them. In previous centuries, Western authority monopolized translation; it helped the construction of an exotic "Other" as a primitive being, devoid of history, who needs the helping hand of the colonizer to become "civilized." With globalization, a part of this view persists, but translation can become an important tool for intercultural mediation and understanding. African literature is part of the global medley of cultures, and it often involves an ethnotextual mental translation or self-translation. To describe their distinct cultural reality, African writers twist the customary usage of European languages, and the resulting "interlanguage" is a hybrid form of African orality and Western writing.

\section{The cultural turn in literary translation studies}


Even though the cultural turn in translation studies is said to have occurred in the $1980 \mathrm{~s}$, its beginning can be traced back further to the 1960s with Eugene A. Nida and Charles R. Taber's work on the cultural adjustments required by the target culture through a descriptive phrase or a functional equivalent. In Toward a Science of Translating (1964), Nida argues that "translation of dynamic equivalence aims at complete naturalness of expression, and tries to relate the receptor to modes of behavior relevant within the context of his own culture" (p.159). The translation of dynamic equivalence hence involves the substitution of SL words with TL words that are more culturally relevant. Nida provides the example of the Biblical phrase "Lamb of God" which is translated as "Seal of God" in the Eskimo language because Eskimo people do not know lambs. Hence, translation is more than a linguistic transfer but an intercultural one.

Apart from Nida and Charles R. Taber's work, most research in literary translation studies focused on micro-level linguistic units up until the 1980s when the "Manipulation School" found interest in the macro-level cultural context of the translation process, inspired by Itamar Even-Zohar's polysystem theory, which regards literature as a system of overlapping systems. In The Manipulation of Literature: Studies in Literary Translation (1985), Theo Hermans sums up the central claim of the "Manipulation School" as follows:

Translation is, of course, a rewriting of the original text. All rewritings, whatever their intention, reflect a certain ideology and a poetics and as such manipulate literature to function in a given society in a given way. Rewriting is manipulation, undertaken in the service of power [...] and the history of translation is the history also of literary innovation, of the shaping power of one culture upon another. (p. ix)

This manipulation in the translation process can be conscious or unconscious. Susan Bassnett and André Lefevere believe that translators, like writers, are socio-historically constructed subjects. Lefevere uses the concept of the "refracted text" as one that has been adapted for a given audience, "with the intention of influencing the way in which that audience reads the work" (2000, pp. 234-235). The translator's understanding and translation of the SL text often depends on their own social and historical backgrounds, so their task can be influenced by ideological manipulation, be it religious or political ideology, expectations of the dominant culture, intended readership, etc.

\section{The postcolonial ${ }^{1}$ turn in literary translation studies}


The cultural turn has widened the scope of research in translation studies to the literatures of former colonized countries. Historically, translation allowed colonial administration to understand and rule indigenous populations. Gayatri Spivak uses the terms "translationese" to describe such translations that discard the cultural identity of politically weak peoples and involve "a betrayal of the democratic ideal into the law of the strongest" (2000, p. 400). Even if translation has often been subject to power relations, it can play an important role in the decolonization of minds when postcolonial authors use it as a strategy of subversion and resistance.

The use of former colonial languages is one of the most important issues in postcolonial literatures. Language is "the medium through which a hierarchical structure of power is perpetuated, and the medium through which conceptions of 'truth,' 'order,' and 'reality' become established" (Ashcroft et al., 1989, p. 7). Hence, postcolonial literatures clearly reflect what Crystal calls "the conflict between intelligibility and identity" (1997, p. 134). Postcolonial writers share ambivalent attitudes towards the English language for, in their view, both its alienating and liberating potentials. They choose to write in a European language, but most of them recognize that the process at work "involves 'some sort of translation' that 'approximates' the meaning in the Source Language" (Zabus, 1995, pp. 315-316). Hence, while they feel the need to preserve their endangered mother tongues, they also need a widely used language to have a large readership. Translation helps them in solving this compromise.

Nigerian writer Chinua Achebe admits that abandoning one's mother tongue for the colonial one "looks like a dreadful betrayal and produces a guilty feeling," but for him, "there is no other choice," because, he says; "I feel that the English language will be able to carry the weight of my African experience. But it will have to be a new English, still in full communion with its ancestral home but altered to suit new African surroundings (1975, p. 103). This appropriation of the colonial language creates a hybrid literary text that merges African and European elements, and hence allows previously silenced cultures to enter the discursive arena. It is "a search for a compromise between African and European language expression, a middle passage, a blend of source and target language translation strategies, fine-tuned and adapted to deal with the linguistic and cultural hybridity, or métissage, characteristic of the postcolonial text" (Bandia, 2008, p. 5). At the opposite pole, Kenyan writer Ngũgĩ Wa Thiong'o is one of the strongest adherents to the separatist stance. For him, postcolonial writers need to heal the cultural sores of their continent by writing in their indigenous languages, as he does by writing in Kikuyu (a Kenyan dialect), and then translating his works into English to get a wider readership. 


\section{Ethnotextual mental translation}

"Ethnotext" is a concept coined by Chantal Zabus to refer to the ethnic subtext of a literary work; it ranges from "rules of address, riddles, praise-names, dirges to the use of proverbs" (Zabus, 2007, p. 148). By ethnotextual translation, I here refer to the postcolonial writer's "literary act of mental translation" (Ngũgĩ, 2009, p. 8) from their ethnic background to the foreign language. Bill Ashcroft explains it as follows: "Rather than being absorbed into the great swamp of English, writers employed techniques of inner translation and transformation to produce an English that was culturally located, culturally specific, and clear in its identification of difference. This rendered the language itself as translation" (2014, p. 20). The focus in this quote is on Anglophone writers, but it can be applied on all Europhone ones. Ashcroft explains the "metonymic gap" created by this act of inner or mental translation, by which a part of the author's culture stands for the whole; it creates a gap between their own culture and that of the language they are borrowing. It has an ethnographic role because it is a sign of cultural difference and identity affirmation. This practice involves the domestication of the former colonial language through some translation techniques that serve as cultural signposts.

In this process of postcolonial translation, cultural distance hinders the translation of a vast repertoire of terms related to religions, myths, legends and proverbs. The Sapir-Whorf hypothesis suggests that every language expresses the specific worldview of its native speakers, and that different languages predispose their speakers to think differently. Hence, this distance creates what J.C. Catford calls a "cultural untranslatability" which happens "when it is impossible to build functionally relevant features of the situation into the contextual meaning of the TL text" (1978, p. 94). In his prefatory notes to Emperor Shaka the Great: A Zulu Epic, for instance, Mazisi Kunene says:

The translation of the epic does not claim to correspond word for word with the original Zulu epic. I have tried to give a faithful but free translation of the original. I have also cut out a great deal of material which would seem to be a digression from the story, a style unacceptable in English but characteristic of deep scholarship in Zulu. [...] Many concepts in Zulu are either untranslatable or they require reinterpretation. Many words in English do not mean exactly the same things in Zulu. (1979, p. xxvii)

This "selective lexical fidelity" to one's native tongue shows a "cultural distinctiveness" for which some writers provide glossaries to help their readers, but others provide no explanations 
because, in their view, "glossing gives the translated word, and thus the 'receptor' culture, the higher status" (Ashcroft et al., 1989, p. 66). By leaving untranslated words in their texts, therefore, most postcolonial writers intentionally urge foreign readers to investigate their culture and language.

Achebe's Things Fall Apart (1958) is a landmark of Africanized European discourse with its distinctive use of Igbo proverbs, images, rhythms and syntactic turns from the Igbo vernacular language of the author. He uses a translation technique that Zabus calls "cushioning," putting the SL and TL words side by side, and "contextualizing", providing information about the SL context (2007, p. 158). For example, "The elders, or ndichie, met to hear the report of Okonkwo's mission" (Achebe, 1958, p. 9) and "He had a bad chi or personal god, and evil fortune followed him" (ibid., p. 13). He also translates Igbo proverbs like "When mother-cow is chewing grass its young ones watch its mouth (ibid., p. 50) which is the equivalent of "Like father like son." Even though proverbs are a mark of cultural distinctiveness, they lose their vividness in translation since they are isolated from their cultural frame of reference.

In Wole Soyinka's The Interpreters, the language is also characterized by the use of Yoruba words, proverbs, symbols and metaphors. The title of the novel probably reflects Soyinka's purpose of creating a "new generation of interpreters" (1965, p. 178) as intercultural translators or mediators. Foreign readers of Soyinka's The Interpreters encounter considerable difficulties in understanding some unfamiliar expressions and images directly calqued from a language that expresses a completely different worldview. He translates many Yoruba proverbs such as: "When the Bale borrows a horse-tail he sends a menial" (ibid., p. 92) and "The rains of May become in July slit arteries of the sacrificial bull” (ibid., p. 155). Soyinka also uses the translation technique known as "vernacular transcription" or "transliteration", which refers to the replacement of the Source Language "graphological units" by those of the Target Language (Catford, 1978, p. 66). He transliterates Yoruba appellations of costumes such as "agbada" and "dansiki"; Yoruba music and musical instruments such as "apala" and "maracas"; and Yoruba dishes such as "amala" and "ewudu". He significantly italicizes these words to show their foreignness to English, but when they appear for the second time in the text, he no longer italicizes them probably to mean that he has integrated them into English. Although this practice subverts the English language, it enriches it with neologisms, original images and syntactic structures. In The Interpreters, Soyinka equally invites the foreign audience to penetrate into the authentic Nigerian sociolect. He particularly relies on the technique of "code-switching" by alternating between English and Yoruba, as well as between the different registers of English. 
There are equally numerous sentences in Pidgin English: Matthias says, "Oga, sometimes den go want me for other office. Messenger job for newspaper office no get siddon time ... Oga, make a go drink my own for canteen" $(1965$, p. 69), and the taxi driver says, "Enh, oga mi, you see wetin man dey suffer. Sixteen pound ten na in den charge me for service. Unless we Africans drive all dis foreign firm commor" (ibid., p. 109). The author wants to stress that his Nigerian English is a variety of English just as the British and American ones are; he also wants to show the switching facility among bilingual individuals.

Other postcolonial writers use the translation technique known as "structural calque" or "syntactic fusion," which consists of the arrangement of European words following an African syntax (Ashcroft et al., 1989, p. 68). Ivorian writer Ahmadou Kourouma, for instance, employs this technique in his novel Les soleils des indépendances (1970), creating a hybrid of Malinké syntax and French lexis. Gabriel Okara, in his novel The Voice, also creates a hybrid of Ijaw syntax and English lexis. He creates a metaphorical combat between "the crooked words" of politics in English and "the straight words" of culture in Ijọ (Okara, 1964, p. 117), showing that "the straight words" will finally win over "the crooked words". Zabus, in her "Writing with an Accent" (2013, p. 33), studies Okara's unique experimentation with the English language, a technique that she calls "double-and triple-barreled coinages" as in the following example: "making-people-handsome-day" (1973, p. 70) directly calqued from the Ijọ sentence "kémé mién èbimò èréin." She provides examples of grammatical calques in which the verb is postponed: "Who are you people be?" (ibid., p. 26), "everybody surface-water-things tells" (ibid., p. 34), and "He always of change speaks" (ibid., p. 66). In her view, Okara uses the technique of "relexification" to indigenize the English language; he makes "a new register of communication out of an alien lexicon" $(1995,285)$. These translation strategies happen in the minds of African authors writing in a European language, giving a stamp of authenticity to their contents.

\section{Ethnotextual self-translation}

Apart from the inherent process of mental or inner translation during the act of writing in a colonial language, the cultural turn in translation studies is also characterized by a return to self-translation as an important ideological tool. It is defined as "the process by which a bilingual author transfers his/her own (literary or non-literary) work from one language to another" (Bandín, 2004, p. 36). This practice was common in the Middle Ages when Latin emerged as a Lingua Franca of European communication. Today, self-translation often "occurs in situations of exile or of crude subjugation where one language is attempting to take the place 
of another" (Whyte, 2002, p. 69), in linguistically diverse countries like the USA, Canada, India, Kenya and South Africa. Famous self-translators are Samuel Beckett, Vladimir Nabokov, Rabindranath Tagore and Ngûgî wa Thiong'o, all of whom are bilingual and bicultural writers who want to bridge the two or more languages that define their identity. One of the major advantages of self-translation is that it gives full freedom to deal with the literary work because there is no issue of fidelity. The reason behind it, apart from being ideological, can also be the author's dissatisfaction with translators' unfaithful rendering of their work. In his book on bilingualism and self-translation, with a focus on Julien Green, Samuel Beckett and Vladimir Nabokov, Michael Oustinoff distinguishes between three degrees of self-translation (naturalizing, decentred and (re)creative):

- Naturalizing self-translation bends the text to the standards of the target language by eradicating any interference from the source language. Since it does not take into account the foreignness of the original work, the self-translator adjusts the text according to the expectations of the target culture. They try to translate everything into the language of the target audience, thus erasing all the traces of the source language and culture.

- Decentred self-translation departs from the norms of a given translating doxa, regardless of any value judgment. The self-translator occasionally deviates from the norm to introduce foreign forms into the translated text.

- (Re)creative self-translation involves another creation. The author allows themselves considerable liberty in rewriting the text.

Whatever its type, self-translation closes the work on itself, precluding any subsequent retranslation by someone other than the author, even if the latter is not necessarily the best translator of their text (Oustinoff, 2001, p. 12). It is possible that the author is not well trained in translation or that their linguistic skills are inferior to the translator's. However, with selftranslation, there is no risk of misinterpretation of the SL text because the author knows their work more than any other translator does. The authorial status allows a certain liberty in adding or omitting some elements that the translator would be considered unfaithful in doing so. More importantly, the self-translator knows the ethnotext that underlies the literary work and can better translate proverbs, riddles, chants etc. Hence, self-translation is also a re-creation.

Outstanding among African self-translators is Ngũgĩ Wa Thiong'o who started using his vernacular language, Kikuyu, after a brilliant career in English. In his book, Decolonising the Mind: The Politics of Language in African Literature (1986), he expresses his "farewell to English" as a medium for his writing and his intention to rely on "the age old medium of translation [...] to continue dialogue with all" (p. xiv). His first work in Kikuyu was the play 
Ngaahika Ndeenda (1977), translated as I will Marry when I Want. The second one was Caitaani Mûtharabainî (1980), written during his detention and translated as Devil on the Cross. Through these works, he addresses his people since most of them do not know the English language; his aim is also to mobilize them because he is a Marxist and revolutionary Fanonist writer, committed to the cause of the peasants.

Rachid Boudjedra is an Algerian self-translator who, in the 1960s, started writing in French; then, in the 1980s, he started writing and translating himself into French, alone or with the collaboration of professional translator Antoine Moussali. He says in an interview that he sometimes resorts to the help of a translator to restrain his creativity when he feels that he is rewriting two versions of the same novel (De Gaudemar, 1991, p. 13). In the 1990s, the Algerian Black Decade, he started writing in French again because he could not publish his works in a country shaken by civil war; even his editors apprehended the vengeance of fundamentalists for publishing his very controversial novels.

Readers of Boudjedra's novels can observe discrepancies between the Arabic and the French versions, which means that the process is rather rewriting rather than translation. His novel Attafakkuk in Arabic, translated as Le démantèlement in French (The Dismantling), strikes the reader with the strangeness of its style. Though written in Arabic script, words seem to be arranged according to the rules of French syntax. His "Frenchized" writing is an attempt to test the hospitality of the Arabic language in containing the trace of another underlying linguistic system (Fili-Tullon, 2006, p. 46). Timimoun, his novel written in Arabic and translated into French with the same title, was published in both languages in 1994. In the French version edited by Folio, he adds the subtitle "texte français de l'auteur" ("the author's French text" rather that "the author's translation"). He often employs the techniques of "cushioning" and “contextualizing" (Zabus, 2007, p. 158), placing transliterated Arabic words and their French translation side by side, in addition to information about the meaning and context. For example: "Il chantait, dansait et jouait si bien de l'amzad. Cette sorte de violon touareg qui avait remonté du Hoggar vers le Gourara, à travers les siècles, les rezzou, les vents de sable, les guerres et les passions amoureuses" [He used to sing, dance and play so well the amzad. This sort of Tuareg fiddle which has travelled fom Hoggar to Gourara throughout the centuries, the razzou, sand winds, wars and love passions] (1994, p. 75, my italics). He uses other words such as "ksours" (castles), "chotts" (beaches), "mehari" (dromedaries), etc. By inserting Arabic lexis in the texture of the French language, he gives an enigmatic dimension to his works, meaning that the French language is not capable of rendering the Algerian reality. 


\section{Conclusion}

As illustrated by the previous examples, in postcolonial translation much is always lost in translation, but much can also be gained from the cross-fertilization of different languages and cultures. Although written in a European medium, these African literary works carry an unmistakable African tone. Their authors demonstrate that the introduction of some native lexis into the language of the Other is a deliberate sign of alterity and cultural distinctiveness. In this manner, postcolonial writers have appropriated European languages in a Promethean manner, promoting tolerance towards linguistic varieties which were erstwhile considered as degraded forms.

\section{Endnotes}

${ }^{1}$ Even though "post-" means after, postcolonial theory covers "the imperial process from the moment of colonization to the present day" (before, during and after colonialism). It studies the continuous "preoccupations throughout the historical process initiated by European imperial aggression," such as "migration, slavery, suppression, resistance, representation, difference, race, gender, place, and responses to the influential master discourses of imperial Europe" (Ashcroft et al., 1989, p. 2).

\section{References}

Achebe, C. 2001 (1958). Things Fall Apart. London: Penguin. ---. 1975. Morning Yet on Creation. Day. London: Heinemann.

Akakuru, I.A. "Réflexions sur la littérature africaine et sa traduction." In: Translationdirectory.com. Available at:

$<\mathrm{http}: / / \mathrm{www}$.translationdirectory.com/article1114.htm>.

Ashcroft, B., Gareth G. \& Tiffin, H. 1989. The Empire Writes Back: Theory and Practice in Post-colonial Literatures. London and New York: Routledge.

Ashcroft, B. 2013. "'Bridging the Silence: Inner Translation and the Metonymic Gap." In: Language and Translation in Postcolonial Literatures: Multilingual Contexts, Translational Texts. S. Bertacco (ed.). New York \& London: Routledge, pp. 17 - 31.

Bandia, P.F. 2008. Translation as Reparation: Writing and Translation in Postcolonial Africa. Manchester: St. Jerome.

Bandín, E. 2004. "The Role of Self-translation in the Decolonisation Process of African Countries." In: Estudios Humanísticos. Filología, 26, pp. 3554. Available at: $<$ https://dialnet.unirioja.es/descarga/articulo/897175.pdf $>$.

Bassnett, S. 1998. "The Translation Turn in Cultural Studies." In: Constructing Cultures: Essays on Literary Translation. S. Bassnett 1 A. Lefevere (eds.). Clevedon: Multilingual Matters, pp. 123 - 143.

Boudjedra, R. 1994. Timimoun. Paris: Grasset.

Catford, J.C. 1978. A Linguistic Theory of Translation: An Essay in Applied Linguistics. Oxford: Oxford University Press.

Crystal, D. 1997. English as a Global Language. Cambridge: Cambridge University Press. de Gaudemar, A. 1991. "Entretien avec Rachid Boudjedra." Liberation.

Fili-Tullon, T. 2006. "Entre-langues et réécritures spéculaires La tentation pré-babélienne de Boudjedra." In: Rachid Boudjedra et la productivité du texte. M. Daoud (ed.). Oran: Editions Crasc.

Haruna, J. 2002. "African Writer as Practising Translators: The Case of Ahmadou Kourouma." In: Translator's Journal, Vol. 6, No.4. Available at: 
$<$ http://www.accurapid.com/journal/22kourouma.htm>.

Hermans, T. ed. 1985. The Manipulation of Literature: Studies in Literary Translation. London \& Sydney: Croom Helm.

Kunene, M. 1979. Emperor Shaka the Great: A Zulu Epic. London: William Heineman Ltd.

Lefevere, André. 2000. "Mother Courage's Cucumbers: Text, System, and Refraction in a Theory of Literature." In: The Translation Studies Reader. L. Lawrence (ed.) London and New York: Routledge, pp. 233-249.

Ngũgĩ, W.T. 1986. Decolonising the Mind: The Politics of Language in African Literature. London: James Currey.

---. 2009. Re-Membering Africa. Nairobi: East African educational Publishers Ltd.

Nida. E.A. 1964. Toward a Science of Translating: With Special Reference to Principles and Procedues Involved in Bible Translating. Leiden: E. J. Brill.

Okara, G. 1964. The Voice. London: Andre Deutsch.

Oustinoff, M. 2001. Bilinguisme d'écriture et auto-traduction (Julien Green, Samuel Beckett, Vladimir Nabokov). Paris: L'Harmattan.

Spivak, G.C. 2000. “The Politics of Translation.” In: The Translation Studies Reader. L. Venuti (ed.). New York: Routledge, pp. 397-416.

Soyinka, W. 1965. The Interpreters. London: Heinemann and Andre Deutsch.

Whyte, C. 2002. “Against Self-Translation”. In: Translation and Literature, 11 (1), pp. 64-71.

Zabus, C. 1995. "Relexification." In: The Post-Colonial Studies Reader. B. Ashcroft, G. Griffiths \& H. Tiffin (eds). London and New York: Routledge, pp. 314 - 318.

---. 2007. The African Palimpsest: Indegenization of Language in the West African Europhone Novel. $2^{\text {nd }}$ Enlarged ed. Amsterdam: Rodopi.

---. 2013. “"Writing with an Accent': From Early Decolonization to Contemporary Gender Issues in the African Novel in French, English, and Arabic." In: Language and Translation in Postcolonial Literatures: Multilingual Contexts, Translational Texts. S. Bertacco (ed.). New York \& London: Routledge, pp. 32-47.

Benabed Fella

English Department

Badji Mokhtar - Annaba University

BP12, Annaba: 23000, Algeria

benabed.fella@gmail.com 